\title{
A Tale of Two Jurisdictions: A Focus on the Effect of Regulatory Constraints on Municipal Resilience in Australia
}

\section{Introduction}

Australia has long been lauded as one of the few advanced economies to escape recession subsequent to the Global Financial Crisis (GFC). Credit for Australia's uninterrupted growth since the GFC has been variously ascribed to its strong banking system and robust regulatory agencies which existed prior to the GFC as well as the Commonwealth Government stimulus and bank deposit guarantee schemes initiated after the onset of the crisis (see, for instance Wittenhall 2011; Fenna, 2013). However, Australia was also the beneficiary of a steep rise in demand for commodities from its largest and fourth largest trading partners (China and India, respectively) in the post GFC period. Indeed, Day (2011, p. 23) has conducted empirical analysis to show that 'had growth in export volumes to China been commensurate with prestimulus rates, Australia would have experienced three consecutive quarters of negative real GDP growth'. Less well recognised is the contribution of nett migration to the country - a comparison of the average nett migration for the seven years either side of the GFC reveals an increase of $169 \%$ peaking at 300 million in 2009 (Australian Bureau of Statistics (ABS), 2014). An indication of the pervasive effect of migration on national growth is illustrated by the GDP per capita recording three consecutive quarters of negative growth between September 2008 and March 2009 (ABS, 2014). Thus, while the nation may have escaped a 'technical recession' it would be incorrect to conclude that individuals have not experienced fiscal stress. Moreover, an aggressive fiscal stimulus program, combined with the introduction of a number of unfunded social programs and falling tax receipts associated with a sudden drop-off in commodity prices means that the federal government is now grappling with large deficits over the forward estimates (Commonwealth of Australia, 2015). This in 
turn has prompted the federal government to reduce intergovernmental transfers thus placing stress on state and municipal budgets.

Australia is a federation comprising six independent states (Queensland, New South Wales, Victoria, Tasmania, South Australia and Western Australia) and two Commonwealthcontrolled territories (the Northern Territory and the Australian Capital Territory). There have been two failed attempts to have local government recognised in the federal constitution. As a result, local government remains a 'creature of statute' exercising a limited remit of services according to the delegated powers of the six states and one territory which regulate municipal entities (the Australian Capital Territory (ACT) - which is the seat of the Australian federal parliament - does not have a system of local government; Twomey, 2012). Historically, local government in Australia has been responsible for roads, rates (local government taxes based on property value) and rubbish. In more recent times the local government remit has been expanded to include addressing market failure (for instance, in providing aged care, childcare and medical services in rural locations), recreation services and development planning, as well as limited welfare and law and order functions. Most of the expanded remit has gone unfunded by higher tiers of government (Dollery, Grant and Crase, 2011). State government is responsible for operating inter alia schools, police and fire fighting and providing most of the rail infrastructure. The Commonwealth Government is responsible for public goods such as defence, tertiary education and social security (Drew and Dollery, 2015a). In common with most federalist systems, Australia is characterised by a high degree of vertical fiscal imbalance, with the Commonwealth collecting $81 \%$ of tax revenues, compared with just $3.4 \%$ attributed to local government (ABS, 2014). Intergovernmental grants are therefore an important source of income for Australian municipalities.

This chapter differs from others in this book by placing particular emphasis on the effect of regulatory constraints on municipal resilience. The polar approaches of regulators in 
Australia's two largest jurisdictions - New South Wales (NSW) which regulates 152 municipalities covering a third of the nation's population and Victoria, which regulates 79 municipalities encompassing a quarter of the nation's population -present the ideal institution milieu for such an investigation. For instance, Victorian local government is subject to central auditing (including a thorough system of performance monitoring and performance analysis), has narrowly defined roles for elected representatives (by legislation), was subject to an almost two-thirds reduction in the number of councils in 1994 and has no extant taxation limitations. By way of contrast NSW currently has no system of central auditing (and has only recently introduced an (inadequate) system of performance monitoring), has widely defined roles for elected representatives, is presently in the throes of a forced amalgamation program and has had a system of taxation limitations since 1977. In general, it is probably fair to say that (with the exception of taxation limitations) the Victorian local governments have been subject to heavier regulation and intervention than their NSW peers. This is neither good nor bad, just different - the focus of this paper is to determine whether the different approaches (particularly taxation limitations) manifest as different budget outcomes over the period of study. To facilitate our investigation of the effect of regulatory constraints on municipal resilience we draw on two case studies from each of the jurisdictions. One council from each jurisdiction has been selected from two polar budgetary positions - councils with low volatility negative budget outcomes and councils with highly volatile positive budgetary positions - to expediently highlight the importance of regulatory constraint on municipal resilience.

Section 2 describes the context and, in particular, the features of the two jurisdictions. Section 3 details the methodology used to construct a budgetary position and volatility matrix and inter-temporal analysis of mean budgetary position and volatility over the period spanning 1 July 2008 to 30 June 2014. The results of the analysis are presented in Section 4, with 
particular emphasis on the effect of regulatory constraints on the financial resilience of four exemplar municipalities. The chapter ends with some observations on the importance of regulatory constraints for municipal resilience.

\section{Context}

Local government in Australia has a more limited remit than many of the other countries discussed in other chapters, focussing on providing roads, rubbish removal, development planning and health inspections, and maintaining parks and recreation facilities. In rural areas there is often a demand for local government to provide important services which may not be commercially viable - such as aged care, home and community care, child care and infrastructure to attract and retain medical practitioners. In contrast, metropolitan municipalities often play a complementary role in welfare (for instance, setting up homeless shelters or 'safe' drug injecting sites) and security (for example, setting up a system of video surveillance in entertainment precincts). Road maintenance is the single largest item of municipal expenditure - accounting for approximately a quarter of local government budgets (PwC, 2006). It should be noted that Australian municipalities are responsible for over $80 \%$ of the national road infrastructure (Chakrabarti, Kodikara and Pardo, 2002).

The Australian Accounting Standards Board is the Commonwealth statutory body for prescribing accounting standards. Since 1 January 2005 all Australian entities have reported on a full accruals basis according to AASB equivalent International Financial Reporting Standards (IFRS). Local governments experienced difficulty setting up asset registers and have subsequently adopted inconsistent approaches to reporting depreciation accruals, which account for approximately a quarter of the quantum of expenditure (see, for instance, Drew and Dollery 2015b; Pilcher and Van de Zahn 2010; Pilcher, 2002). Auditing and assurance practices differ for the two jurisdictions, as do a number of other contextual features: 
The New South Wales local government sector comprises 152 general-purpose municipalities. In addition to the functions detailed above, many rural municipalities are also responsible for water and sewerage services (unlike their Victorian peers). The average population size of NSW municipalities in 2013 was 48,026, although individual municipalities had populations ranging from 1,180 to 317,598 . Length of municipal roads maintained by individual municipalities ranged from $65 \mathrm{~km}$ to $3,982 \mathrm{~km}$, with a state mean of $1,090 \mathrm{~km}$. In terms of fiscal responsibilities, the average operating expenditure in 2014 was $\mathrm{A} \$ 39.07 \mathrm{~m}$ (minimum $\mathrm{A} \$ 7.3 \mathrm{~m}$, maximum $\mathrm{A} \$ 266.4 \mathrm{~m})$.

NSW municipalities are not recognised in the state or federal constitution and so they govern under delegated powers conferred via the Local Government Act (1993). The State Local Government Minister has virtually unlimited powers over NSW local government, including the ability to reconstitute boundaries and dismiss elected representatives. In the first decade of the millennium 23 municipalities were forcibly amalgamated, and NSW local government faces imminent amalgamation of approximately a quarter of the extant entities (Drew and Dollery, 2015c). Elections are held for representatives every four years with compulsory voting applying to all citizens. Municipalities have between 6 and 15 representatives, including the Mayor, who is directly elected in only 34 instances. Councillors elect the Mayor (who has both additional ceremonial and executive functions) for the other 118 municipalities on a one-year term. The General Manager of each council is appointed by the elected representatives on a maximum five-year term and the enabling legislation requires that the elected council be consulted on the appointment and dismissal of all senior staff (ILGRP, 2013). There is no statutory requirement for municipalities to have an audit committee and only around one half of municipalities do so (Independent Local Government Review Panel (ILGRP), 2013). 
NSW municipalities extract about $70 \%$ of their revenues through taxes and fees. Taxes are calculated on the unimproved value of land and increases to total taxation take are capped according to a single rate set for the entire state by the Independent Pricing and Regulatory Tribunal (IPART). This tax limitation regime has existed for almost four decades and has resulted in both uneven revenue effort across the state and significant budget constraints (see, Drew and Dollery 2015d). Intergovernmental grants are an important source of income for NSW municipalities. The bulk of the grants emanate from the Commonwealth Government but are allocated by state government grants commissions due to constitutional constraints (see Drew and Dollery 2015a). Grants may be tied to specific purposes or untied. The major untied grants are the Financial Assistance Grants (FAGs), which had a quantum of A $\$ 711.5 \mathrm{~m}$ for NSW in 2015/16 (Department of Infrastructure and Regional Development, 2015). The Commonwealth Government has recently frozen FAGs for three years in order to help repair the federal budget deficits.

\section{Victorian Local Government}

The Victorian local government sector comprises 79 municipalities and had an average population size of 71,245 in 2013 (minimum 3,099, maximum 267,892). Thus, Victoria has fewer and larger (on average) local government entities than NSW. Length of municipal roads maintained by individual municipalities ranged from $42 \mathrm{~km}$ to $11,234 \mathrm{~km}$, with a state mean of $1,659 \mathrm{~km}$. In terms of fiscal responsibilities, the average expenditure in 2014 was $\mathrm{A} \$ 91 \mathrm{~m}$ (minimum $\mathrm{A} \$ 9.55 \mathrm{~m}$, maximum $\mathrm{A} \$ 364 \mathrm{~m}$ ).

Victorian municipalities are recognised in the state constitution, although the Minister still has wide discretion, which has recently been employed to establish proscribed development application fees, performance monitoring metrics and contentious tax limitations starting in the 2016/17 financial year. In 1994 the state government forcibly reduced the number of 
municipalities from 210 to just 78. The subsequent de-amalgamation of Delatite Council in 2002, due to a sustained popular de-amalgamation campaign, increased the number of municipalities to 79. Elections are held for representatives every four years, with compulsory voting applying to all citizens (Drew and Dollery, 2015e). Owners of property who do not reside in the council area also have statutory voting rights, as do corporations occupying property (one representative of each corporation is entitled to vote in elections).

Municipalities have between 5 and 12 representatives, including the Mayor, who is directly elected in only two instances. Councillors in the other 77 municipalities elect the Mayor for a one-year term (Economou, 2010). The General Manager of each council is the sole appointment made by the elected representatives. Victorian municipalities are centrally audited by the Victorian Auditor General's Office (VAGO) and must all operate an audit committee according to section 139 of the Local Government Act (1989) (VAGO, 2015). Central auditing and compulsory audit committees do not currently apply in NSW local government.

Victorian municipalities obtain about $63 \%$ of their revenues from taxes and fees. Taxes are calculated on the capital improved value of land and structures and the rate of taxation is currently determined by elected representatives of the municipalities (Drew and Dollery, 2015d). Intergovernmental grants are also an important source of income for Victorian municipalities. FAGs for Victorian municipalities totalled A\$539.8m in 2015/16 (Department of Infrastructure and Regional Development, 2015). Initial State FAG allocations are based on population size, hence the lower aggregated quantum for Victorian municipalities. 


\section{Methods}

The aim of this chapter is to examine municipal resilience with particular emphasis on the effect of regulatory constraint. To this end the budgetary position and volatility were assessed for the 231 municipalities making up the jurisdictions of NSW and Victoria. Normalised budget positions were calculated for each municipality by taking the operating result from audited financial statements and dividing same by total revenue for the period. This approach accords with regulatory monitoring practices in Victoria. However, in NSW the regulator excludes contributions for capital purposes in its comparative dataset. To ensure a consistent approach for the two jurisdictions, capital contributions were added onto operating results and total revenue for all NSW municipalities. The mean operating result was then calculated for each of the municipalities over the relevant period (the six financial years from 2009 to 2014: publicly available data does not exist for periods prior to $2009^{1}$ and as such the analysis in this chapter is limited to the years immediately after the global financial crisis). Near zero mean budgetary position was taken to be between -1 and $+1 \%$. To stratify municipalities according to volatility, we conducted Ward's method cluster analysis on the entire cohort for the standard deviation of individual normalised budgets calculated over the six financial years (use of the entire cohort in a single cluster analysis is important as it allows for a comparison of relative volatility between the two jurisdictions). Cluster analysis is an empirical strategy for arranging municipalities into homogenous groups. Ward's method joins municipalities to groups which result in the minimum increase to the error sum of squares as measured by Euclidian distance (for further information on cluster analysis see Drew and Dollery, 2014). We grouped the analysis into three clusters representing relatively low, medium and high volatilities. A budgetary position and volatility matrix was then constructed over the six financial years (see Table1).

\footnotetext{
${ }^{1}$ In Australia the financial year is taken from 1 July to 30 June. Therefore, the data encompasses the period from 1 July, 2008 through to 30 June 2014.
} 
Table 1. Budgetary Position and Volatility of New South Wales and Victorian Municipalities (number of municipalities in each cell is presented as a percentage of the entire 231 council cohort in parenthesis).

\begin{tabular}{|c|c|c|c|}
\hline $\begin{array}{l}\text { Budgetary } \\
\text { position } \\
\text { Volatility }\end{array}$ & Negative & Around zero & Positive \\
\hline Low & $\begin{array}{l}17 \text { NSW }(7.4 \%) \\
1 \text { Victoria }(0.4 \%)\end{array}$ & $\begin{array}{l}9 \text { NSW }(3.9 \%) \\
3 \text { Victoria }(1.3 \%)\end{array}$ & $\begin{array}{l}100 \text { NSW (43.3\%) } \\
67 \text { Victoria (29\%) }\end{array}$ \\
\hline Medium & $\begin{array}{l}4 \mathrm{NSW}(1.7 \%) \\
0 \text { Victoria }(0 \%)\end{array}$ & $\begin{array}{l}2 \mathrm{NSW}(0.9 \%) \\
0 \text { Victoria }(0 \%)\end{array}$ & $\begin{array}{l}1 \mathrm{NSW}(0.4 \%) \\
2 \text { Victoria }(0.9 \%)\end{array}$ \\
\hline High & $\begin{array}{l}6 \mathrm{NSW}(2.6 \%) \\
0 \text { Victoria }(0 \%)\end{array}$ & $\begin{array}{l}0 \mathrm{NSW}(0 \%) \\
0 \text { Victoria }(0 \%)\end{array}$ & $\begin{array}{l}13 \text { NSW }(5.7 \%) \\
6 \text { Victoria }(2.6 \%)\end{array}$ \\
\hline
\end{tabular}

Notably, the majority of municipalities experiencing a mean negative budgetary position over the six years were located in NSW (27 out of the 28 'negative' municipalities). It is also clear that the level of budget volatility was far higher for NSW municipalities than for their Victorian peers (19 of the 25 high-volatility municipalities were domiciled in NSW).

These results seem to suggest that differences in regulatory approaches might have an important effect on muinicipal resilience. In order to investigate this matter further we plotted the mean normalised budget position and standard deviation for each jurisdiction to examine inter-temporal trends. We then conducted four case studies drawn from diametrically opposed cells of the budgetary matrix: two low-volatility, negative budgetary position municipalities (Central Darling (NSW) and Monash (Victoria)) and two positive high-volatility municipalities (Carrathool (NSW) and Loddon (Victoria)). The extreme positions of the matrix were selected rather than the most representative clusters under the assumption that regulatory effects were most likely to be seen first at the margins. This desire to emphasise 
the effects of regulatory constraints on resilience was also reflected in the careful choice of exemplar councils. For instance, Central Darling Shire was selected as it is the sole example of Australian government financial failure and Carrathool was chosen because it achieved very different budgetary outcomes despite being faced with quite similar environmental constraints. Moreover, Monash was the sole example of a Victorian council with lowvolatility negative budgetary position, whilst Loddon provided a good example of the need for revenue flexibility in the face of catastrophic natural disasters. The case studies were based on artefacts taken from the local media and official documents (such as transcripts of public inquiries and council submissions to public consultations).

\section{Results}

To provide a comprehensive understanding of the effect of regulatory constraint on municipal resilience in the post GFC period we considered the matter from two complimentary perspectives. First, we conducted an inter-temporal comparison in order to establish whether there were in fact clear differences between the two jurisdictions and therefore provide an empirical basis for suggesting that the disparate regulatory environments might have a bearing on the budgetary positions of councils. We then conducted a close examination of four councils in order to understand how regulatory settings, in particular, influence municipal resilience.

Inter-temporal Analysis of Jurisdiction Level Responses Post GFC

Figure 2 illustrates inter-temporal trends in budget positions at a state jurisdiction level, as well as a measure of the spread of budget positions for each of the two jurisdictions over the (financial year) period 2009 to 2014 inclusive. In order to interpret Figure 2 it is important to be aware of events which occurred over this time. The first major disruption to council budgets occurred as a result of the Commonwealth Government's response to the GFC. To 
assist municipal cash flows the Commonwealth pre-paid part of the 2010 allocation of FAGs into the 2009 financial year (Parliament of the Commonwealth of Australia, 2009). Later, in February 2009 the federal government partnered with local government to roll out over $A \$ 1$ billion of the fiscal stimulus program (Parliament of the Commonwealth of Australia, 2009). At about the same time, Victorian municipalities were faced with infrastructure write-offs and increased demand for welfare assistance resulting from the February 2009 Black Saturday bushfires, which affected 78 communities, covered 400,000 hectares and killed 173 residents (Country Fire Authority, 2015). Municipal natural disaster response explains why Victorian municipalities as a cohort had a steeper downward gradient in their mean budget position between the 2009 and 2010 financial years (see also, Institute of Public Works Engineering Australasia, 2014).

\section{Figure 2. Budgetary Position and Volatility of New South Wales and Victorian Municipalities Since the Global Financial Crisis.}

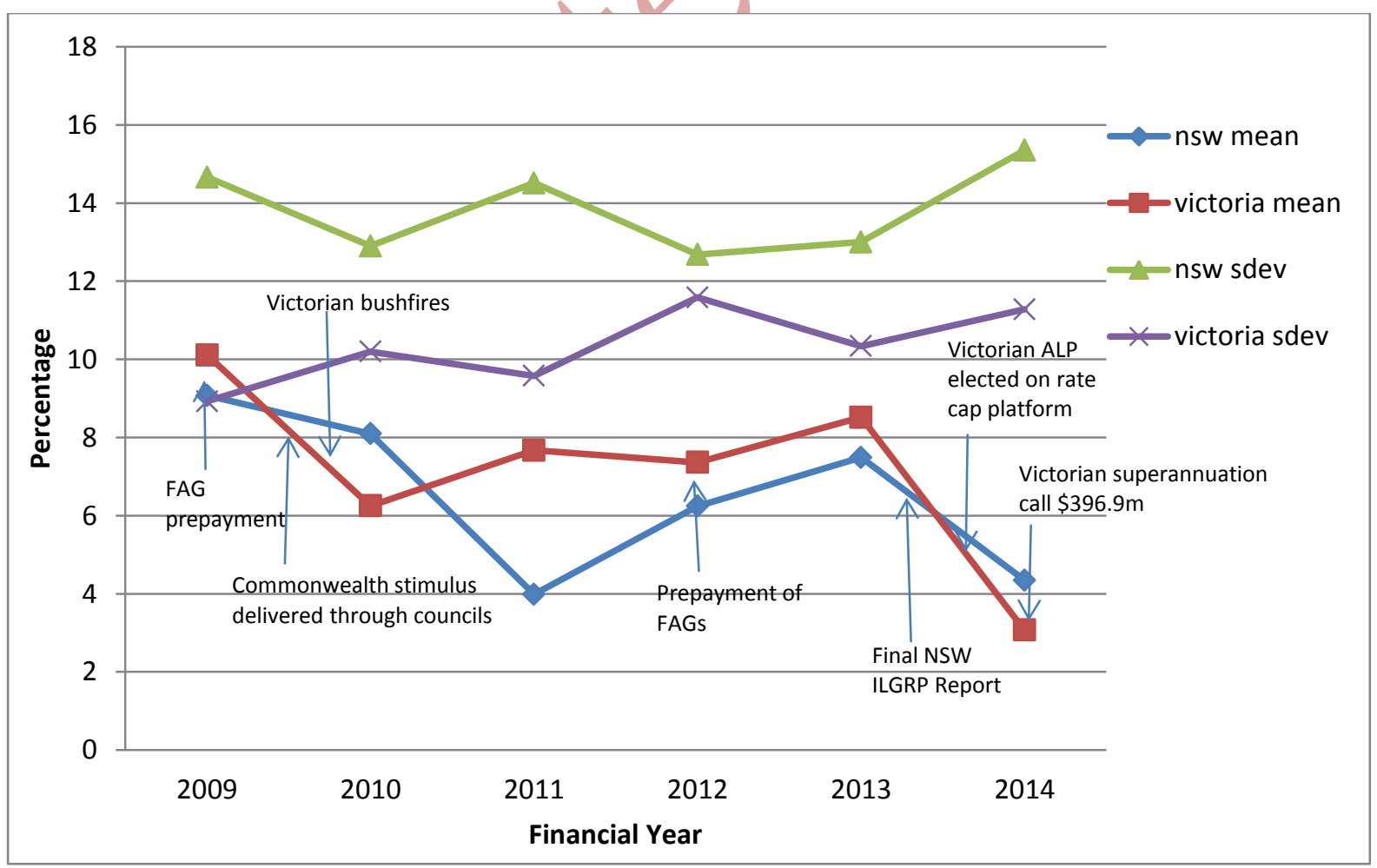


The strategy of prepaying FAGs was then repeated for the 2012 financial year, wherein half of the FAG allocation for 2012/13 was paid a year early- this time in order for the federal government to attempt to manufacture a budget surplus for the subsequent financial year (Comrie, 2013). Moreover, NSW municipalities recognised A $\$ 384 \mathrm{~m}$ in investment losses during 2009-2012, associated with collateralised debt obligations, capital protected and managed fund products (Department of Premier \& Cabinet Division of Local Government (DLG), 2013). 'Lehman Brothers, in particular, were active in the WA [Western Australia] and NSW markets' (Parliament of the Commonwealth of Australia, 2009,p. 64). Victorian municipalities had little exposure to high-risk investment products due to more conservative investment regulatory guidelines issued by the state regulator.

Notably, the NSW jurisdiction had higher rates of volatility over the entire domain. This is likely the result of the strict tax limitation regime which made it very difficult for municipalities to mitigate volatile expenditure demands with own-source revenue increases. The NSW jurisdiction also had lower average normalised budget positions for four of the six financial periods. Given that the remaining two periods were characterised by significant shocks to which only Victorian municipalities were exposed, this overall result may be taken to suggest that regulatory settings (in particular tax limitations and investment guidelines) are extremely important to municipal resilience.

The responses of individual municipalities to the various budget disruptions over the (financial) period 2009 to 2014 inclusive led to two very different regulatory reactions. In the case of Victoria, relatively high increases to taxation rates, executed to arrest declining budgetary positions, led to the state opposition party running on an election platform which inter alia included introducing municipal tax limitations (proposing that tax increases would be capped at the rate of inflation as measured by the Consumer Price Index). When the opposition party was elected in May 2014 they quickly introduced preparations to establish 
tax limitations to commence in the 2015/16 financial year (however, in response to strident stakeholder objections, the introduction of tax limitations was deferred in early 2015 to the 2016/17 financial year) (Australian Broadcasting Corporation (ABC), 2015a). In addition, Victorian municipalities were hit with a one-off defined superannuation call in the order of an aggregate $\mathrm{A} \$ 396 \mathrm{~m}$ to meet unfunded defined superannuation liabilities (Municipal Association of Victoria (MAV), 2012). In contrast, NSW municipalities, which had suffered declining budgetary positions principally as a result of the longstanding tax limitation regime, came in for a different type of regulatory intervention. The NSW Government established an 'independent' advisory panel which recommended a program of radical forced amalgamations (Independent Local Government Review Panel (ILGRP), 2013).

\section{Individual Council Responses to Shocks}

Central Darling Shire in NSW (exhibiting a six-year average budgetary position of $-2.22 \%$ ) has had the most spectacular outcome arising from post-GFC budget disruptions, having been placed into financial Administration in December 2013 when it became clear that the municipality was no longer solvent. This period of Administration has since been extended to 2020 following a public inquiry which identified a long history of failed regulatory interventions stretching back to January 2011 (Colley, 2014). It is the first instance of government financial failure in Australia.

Elected representatives (councillors) were quick to cite inadequate levels of intergovernmental grants as the cause behind the liquidity crisis confronting the municipality (Drew and Campbell, 2016). It was argued by councillors that the high infrastructure burden coupled with a small population spread over a vast distance equivalent to one-fifth of the size of the United Kingdom meant that only increased intergovernmental grant transfers could ensure a sustainable municipality. In addition, councillors drew attention to the burden 
created by an increasing obligation of municipal government to address market failure (such as the purchase and operation of the Wilcannia Post Office after the previous owners fell into receivership) (Drew and Campbell, 2016).

However, the inquiry was scathing of what it perceived to be the 'fatalistic attitude [of elected representatives] about the councils financial viability' (Colley, 2014, p. 9) In particular, the Commissioner of the inquiry condemned 'councillors [who] blamed, and continue to blame the Federal and State governments, including various government agencies for a failure to provide funding to bail the Council out of the financial crises' (Colley, 2014, p. 9). The attitude of the council might indeed have been the result of an extreme sense of fatalism as concluded by the Commissioner. However, it is also a possibility that the events leading up to the Administration period may have been the result of brinkmanship. Rather than reducing services, councillors expanded some services and when it became apparent that the council was approaching insolvency wrote to their Member of Parliament demanding an immediate cash injection of $\$ 2$ million and a review of the quantum of grant transfers to the Shire (Colley, 2014, pp. 28-31). The state government response seems to have taken the council by surprise: the shire did not get a cash injection and was forced into administration, however, it did receive an increase in its FAG allocations in the order of $\$ 800,000$ per annum from 2012/13 levels (Drew and Campbell, 2016). In any event, the conclusion of the public inquiry was that the liquidity crisis could only be addressed through deep and enduring cuts to municipal services. Moreover, the Commissioner determined that the current elected representatives did not have an adequate commitment to the recovery plan and therefore declared that the municipality would need to continue in Administration for a further six years (Colley, 2014).

A number of interesting observations can be made regarding the municipal resilience of Central Darling Shire. In the first instance, it is clear that tax limitations imposed by 
regulatory authorities exerted a direct influence on the coping capacity of elected representatives, essentially dictating a high level of dependency on intergovernmental grant transfers for revenue side approaches to resolving the liquidity problem. Second, the transcripts from the public inquiry suggest that a combination of municipal tax limitations along with a high level of grant transfers had resulted in a disconnect between resident demand for enhanced services and own-source revenue (Colley, 2014). Finally, it is clear that elected representatives of the municipality suffered from diminished anticipatory capacity: it appears from the transcripts of the inquiry that the councillors really did believe that the state government would bail the municipality out of the liquidity crisis. Moreover, councillors seemed unable to anticipate the outcome of the inquiry: following the release of the Commissioner's recommendations the Mayor was cited as saying that he 'was shocked to hear the suspension will stay' and that the 'councillors were ready to return to work, and even had plans underway for the Administrator to hand back control' (Local Government Career, 2014).

In Victoria there was just one council with a negative budgetary position over the six financial years subsequent to the GFC - Monash (six-year average budgetary position of 1.66\%). In its submission to the Essential Services Commission (ESC) regarding the proposed tax limitation framework, the municipality boasted that it 'has consistently kept rates as low as possible and has the lowest rates of all 79 Victorian municipalities' and that it 'has proudly maintained the lowest rating status for several years' (Monash City Council, 2015). In one sense Monash Council appears to have a self-imposed tax limitation regime which has led to similar results to those experienced by some NSW municipalities deteriorating budgetary positions over an extended period of time. However, unlike Central Darling, Monash Council was able to anticipate a looming crisis and was prepared and able to take actions on the expenditure side to mitigate poor budgetary outcomes. In January 2014 , 
Monash Council voted to sell its two aged-care facilities (housing 165 residents) to Royal Freemasons for $\mathrm{A} \$ 21.8 \mathrm{~m}$. This sale was expected to save the council approximately $\mathrm{A} \$ 1 \mathrm{~m}$ per annum in subsidies for the facilities as well 'several millions of dollars in capital works in the short term' (Lake, 2015). It is important to note one very big difference between the two municipalities - Central Darling is a rural council situated $950 \mathrm{~km}$ west of Sydney, whilst Monash is a metropolitan council located just $25.8 \mathrm{~km}$ from Melbourne, the Victorian capital. Consequently, Monash had the advantage of being able to find commercial operators which could make a profit operating council assets, whereas Central Darling had only the option of closing facilities - the shire's remote location makes many commercial operations simply not viable. Therefore, it is clear that Monash had significantly greater coping capacity by virtue of its geographical position, but also greater anticipatory awareness of the need to adapt and mitigate revenue side budgetary constraints.

On the opposite side of the matrix are the two exemplar high volatility 'positive' municipalities. Carrathool (six-year mean normalised budgetary position of 19.77\%), like Central Darling, is a rural NSW/council located some distance west of Sydney $(675 \mathrm{~km})$ and thus faces similar environmental constraints. In the 2012 financial year (prior to the investigations of Central Darling) the two municipalities faced almost identical circumstances. For instance, Carrathool had a population of 2,668 with an average income of $\mathrm{A} \$ 38,064$ and a council operating expenditure of $\mathrm{A} \$ 17 \mathrm{~m}$, whilst Central Darling had a population of 2,108 with an average per capita income of $A \$ 38,248$ and an operating expenditure of $\mathrm{A} \$ 16.3 \mathrm{~m}$ (Office of Local Government (OLG), 2015). The big difference between the two NSW municipalities was on the revenue that each was able to extract by virtue of the tax limitation measures. Tax limitations were based on incremental increases on the extant tax rate charged in 1977 - therefore municipalities which had small differences in rate revenue in 1977 could conceivably end up with large differences owing to the 
compounding effect of almost four decades (Abelson and Joyeux, 2015). Thus, as at 2012 Carrathool was collecting well over four times the municipal taxes as was Central Darling Shire despite roughly comparable capacity of residents to pay (Office of Local Government, 2015). It should be noted that municipalities have the option to apply for special rate variations (SRV) to increase municipal taxes above regulated annual increase levels. However, this process is expensive (owing to the regulatory requirements to demonstrate need and community support) and politically charged, and one to which few municipalities are prepared to commit (in 2012 just 13 municipalities applied for SRVs)(IPART, 2015). In short, Carrathool Council had greater coping capacity (through higher budget redundancies to buffer against shocks) than Central Darling Shire, almost entirely as a result of higher revenue take afforded under the tax limitation regime. This serendipitous situation wherein regulated tax revenues far exceeded need meant that the leadership team at Carrathool could afford to exhibit an attitude of contentment at the same time as their peers were confronted by insolvency.

In Victoria, Loddon Shire (215km NNW of Melbourne) has had a highly volatile but positive mean normalised budget outcome over the six financial years which stands in stark contrast to the position of Monash council which also had - at least legislatively - the flexibility to adjust taxation revenues to match need. Volatility in the results can be directly attributed to a number of natural disasters which occurred in the rural area: between September 2010 and January 2011, Loddon Shire experience three major flood events which destroyed an estimated $\mathrm{A} \$ 42 \mathrm{~m}$ of road and bridge infrastructure (Institute of Public Works Engineering Australasia (IPWEA), 2014). The municipality was able to access national disaster relief funding and execute the restoration works in the stipulated two-year time frame and $\mathrm{A} \$ 8 \mathrm{~m}$ under budget (IPWEA, 2014). Consistent with other rural municipalities in Australia, Loddon Shire has a number of facilities to meet demand associated with market 
failure, including five kindergartens and an $\mathrm{A} \$ 2.5 \mathrm{~m}$ home-care service (ABC, 2015b). The council credits its solid budget outcomes to the careful control of costs and the flexibility to set rates at a level commensurate with demand (Loddon was not subject to municipal tax limitations as were the NSW municipalities). For instance, Loddon Shire increased rate revenue by $7 \%$ in $2012,5 \%$ in 2013 and $5.9 \%$ in 2014 . Yet over the same period NSW council tax limitations allowed for increases of only $2.8 \%$ in $2012,3.6 \%$ in 2013 and $3.4 \%$ in $2014^{2}$ (IPART, 2015). This comparison highlights the importance of municipal tax flexibility in allowing municipalities to respond to shocks and thus produce positive budget outcomes. Indeed, the Mayor of Loddon Shire has recognised that the introduction of similar tax limitations in Victoria would impose severe constraints on the municipal budget, noting that 'we are going to have to start a conversation with our community around what services we might be able to reduce' (ABC, 2015b). Thus, Loddon Shire is exhibiting great anticipatory awareness regarding the effect of regulatory constraints on municipal resilience. However, the Mayor asserts that the plan will ultimately result in unsustainable municipalities because 'our residents do not want a cutback in Council services' (ABC, 2015b). Thus, whilst the past behaviour of Loddon Shire might best be described as adaptive it appears that looming regulatory constraints are creating an atmosphere of fatalism.

\footnotetext{
${ }^{2}$ Tax limitation levels fluctuate in accordance with IPART's local government cost index.
} 


\section{Conclusion}

Australia has been widely lauded as one of the few developed economies to have escaped recession subsequent to the GFC. However, some of the measures taken by the

Commonwealth to provide fiscal stimulus in the wake of the economic shock appear to have resulted in significant budget disruption for municipalities. Moreover, local governments have been exposed to a number of other shocks arising from natural disasters, loss of investment principal associated with 'risky' financial products and extraordinary defined benefits superannuation calls.

The financial resilience of individual municipalities seems to have been influenced, at least in part, by jurisdiction level constraints - in particular, investment guidelines and tax limitations. NSW municipalities were exposed to significant risk as a result of inadequate investment guidelines (at the state regulator level) and they produced highly volatile budget outcomes as a consequence of revenue constraints associated with the tax limitations. In contrast, Victorian municipalities had far lower budget volatility and produced higher mean budget positions despite catastrophic natural disasters and almost $\mathrm{A} \$ 400 \mathrm{~m}$ of unexpected superannuation calls. In fact, an examination of the financial resilience of all 231 local governments over the period 2009 to 2014 inclusive revealed that just one of the 28 negative budgetary position municipalities was domiciled in Victoria and 19 of the 25 high volatility municipalities were located in NSW. This is compelling evidence of the critical effect of regulatory policy on municipal financial resilience.

The importance of regulatory settings for financial resilience was further illustrated through a comparison of two municipalities from each jurisdiction drawn from diametrically opposed positions on the budgetary position and volatility matrix. Specifically, we compared the two NSW local governments of Central Darling (a low volatility 'negative' municipality placed into almost seven years of Administration due to poor liquidity) and Carrathool (a high 
volatility 'positive' council). Both municipalities operated in similar contexts and under comparable operating expenditures. However, the resilience of the respective municipalities was entirely disparate as a result of significant difference in revenue take, attributable to the long-standing tax limitation regime. Two illustrative Victorian cases were also examined in order to elucidate post-GFC municipal resilience. In the first case - Monash - significant revenue constraints were also in place (this time as a result of self-imposed tax limitations). However, the evidence suggests that the officials at Monash had a better understanding of their financial predicament than the officials at Central Darling and they have implemented a number of expenditure side measures (such as selling the two aged-care facilities) to mitigate the poor budgetary position. At the opposite end of the spectrum, Loddon Shire in Victoria was able to engineer a mean positive budgetary outcome through careful control of costs and exercising their flexibility to set taxes at a level commensurate with need.

It might be noted that the absence of self-regulatory approaches to resilience, evident in our sample, may be due to the sampling approach used in this chapter: we specifically, sought out examples of extreme outcomes to highlight the effect of regulatory constraint which we argued are most likely to be first perceived at the margins. It is entirely possible that local governments in the better represented cells of the budgetary position matrix exhibited other resilience behaviours such as self-regulation. However, our approach has uncovered tentative evidence of a novel resilience behaviour - brinkmanship (Central Darling Shire). In nations such as Australia where an important source of revenue is provided by a system of intergovernmental transfers not governed by robust empirical methodology, there is an incentive for local governments to try to exploit these so-called soft budget constraints (Oates, 2005). As fiscal austerity starts to bight (in combination with exacerbating factors such as taxation limitations) it is entirely possible that we will soon observe new instances of municipalities failing to cut services despite falling revenues in the hope that they might 
receive a bailout (either directly or through changes to grant transfers) should the finances deteriorate to crisis point.

Ironically, the Victorian Government is set to introduce a tax limitation regime which will largely bring to an end the revenue flexibility which allowed Victorian municipalities to produce superior budget outcomes over the post-GFC period. Meanwhile, the NSW Government is in the throes of a forced municipal amalgamation program, largely designed to arrest the decline of local government budget positions - a decline attributable in large part to the longstanding tax limitation regime (Abelson and Joyeux, 2015).

In summary, this chapter has demonstrated that regulatory policy can exert a large influence on municipal budgetary position and volatility. In particular, tax limitations and lax investment guidelines can seriously diminish resilience. However, it is also true that representatives' understandings of financial vulnerability and the willingness to exercise spending restraint can have important implications for individual municipalities, notwithstanding the aforementioned constraints. In addition, we have demonstrated the importance of geographical context on municipal resilience. Specifically, low population size, low population density and large distance from major conurbations provides both little opportunity to outsource service provision as well as high demand on local government to address market failure. Finally, our analysis suggests bleak futures for municipalities within the two jurisdictions as the first signs of fiscal austerity start to emerge through the three-year freeze to intergovernmental grants. In particular, the imminent introduction of tax limitations to Victoria is a matter of great concern. Moreover, the NSW regulatory authorities seem unwilling to confront the problems caused by the longstanding tax limitation regime and instead have embarked on a disruptive program of forced amalgamation. 


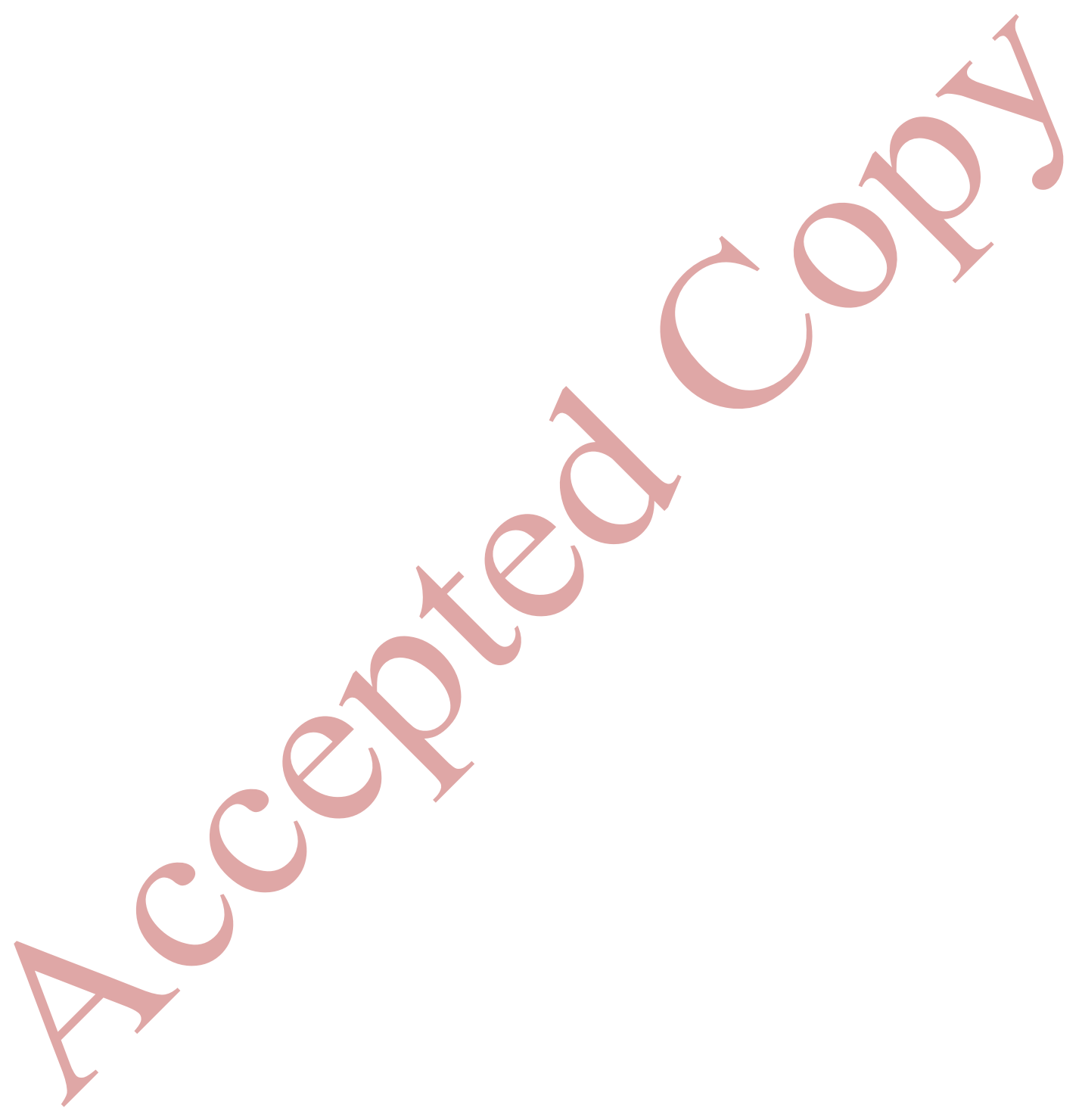




\section{References}

Abelson, P. and Joyeux, R. (2015) New Development: Smoke and Mirrors - Fallacies in the New South Wales Government's Views on Local Government Financial Capacity. Public Money \& Management, 35(4): 315-320.

Australian Bureau of Statistics (ABS) (2014). Migration, Australia, 2013-14. ABS: Canberra. Australian Bureau of Statistics (ABS) (2015). Taxation Revenue, Australia, 2013-14. ABS: Canberra.

Australian Broadcasting Corporation (ABC) (2014). Civic Offices at central Darling Shire Declared Vacant, Permanent Administrator Appointed. ABC: Sydney.

Australian Broadcasting Corporation (ABC) (2015a). Victorian Councils Praise Decision to Delay Rate Capping. ABC: Melbourne.

Australian Broadcasting Commission (ABC) (2015b). Loddon Shire Budget Proposes 5.5pc Rate Rise as Mayor Airs Uncertainty About Future Council Income. ABC: Melbourne.

Chakrabarti, S., J. Kodikara and Pardo, L. (2002). Survey Results on Stabilisation Methods and Performance of Local Government Roads in Australia. Road \& Transport Research 11(3): 3-16.

City of Monash (2015). Local Government Rates Capping and Variation Framework Review Submision. City of Monash: Monash.

Colley, R (2014). Central Darling Shire Council Public Inquiry Report.

Comrie, J. (2013). Roadmap to Financial Sustainability for Local Governments in NSW. JAC Comrie Pty Ltd: Sydney. 
Commonwealth of Australia (2015). Budget 2015-16: Budget Strategy and Outlook. Budget Paper No. 1. Commonwealth of Australia: Canberra.

Country Fire Authority (CFA). (2015). About Black Saturday 2009. Accessed $11^{\text {th }}$ September 2015 at: http://www.cfa.vic.gov.au/about/black-saturday/

Day, C. (2011). Chinas' Fiscal Stimulus and the Recession Australia Never Had. Agenda, 18(1): 24-34.

Department of Infrastructure and Regional Development (DI\&RD) (2015). Financial Assistance Grants to Local Government. DI\&RD: Canberra.

Department of Premier \& Cabinet Division of Local Government (DLG) (2015). Review of NSW Local Government Investments. DLG: Sydney.

Dollery, B., Grant, B. and Crase, L. (2011). Love They Neighbour: A Social Capital Approach to Local Government Partnerships. Australian Journal of Public Administration, 70(2): 156-166.

Drew, J. and Campbell, N. (2016). Autopsy of Municipal Failure: The Case of Central Darling Shire. Australasian Journal of Regional Science, In Print.

Drew, J. and Dollery, B. (2015a). Road to Ruin? Consistency, Transparency and Horizontal Equalisation of Road Grant Allocations in Eastern Mainland Australian States. Public Administration Quarterly, 39(3): 517-545.

Drew, J. and Dollery, B. (2015b). Inconsistent Depreciation Practice and Public Policymaking: Local Government Reform in New South Wales. Australian Accounting Review, 25(1), 28-37. 
Drew, J. and Dollery, B. (2015c) Less Haste More Speed: The Fit for Future Reform Program in New South Wales Local Government. Australian Journal of Public Administration, DOI: 10.1111/1467-8500.12158.

Drew, J and Dollery, B (2015d). A Fair Go? A Response to the Independent Local Government Review Panel's Assessment of Municipal Taxation in New South Wales. Australian Tax Forum, 30: 1-19.

Drew, J and Dollery, B (2015e). Breaking Up is Hard to do: The De-amalgamation of Delatite Shire. Public Finance and Management, 15(1): 1-23.

Drew, J. and Dollery, B. (2015f). Summary Execution: The Impact of Alternative Summarization Strategies on Local Governments. Public Administration Quarterly, In Print. Economou, N. (2010). Parties, Participation and Outcomes: The 2008 Victorian Local Government Elections. Australian Journal of Political Science, 45(3): 425-436.

Essential Services Commission (ESC) (2015). A Blueprint for Change: Local Government Rates capping \& Variation Framework Review. ESC: Melbourne.

Fenna, A. (2013). The Economic Policy Agenda in Australia, 1962-2012. Australian Journal of Public Administration, 72(2): 89-102.

Independent Local Government Review Panel (ILGRP) (2013). Revitalising Local Government - Final Report of the NSW Independent Local Government Review Panel. Sydney: ILGRP. Independent Pricing and Regulatory Tribunal (IPART) (2012). Special Rate Variations Applications \& Determinations. IPART: Sydney. 
Institute of Public Works Engineering Australasi (IPWEA). (2014). Loddon Shire Council: Road Infrastructure Flood Program. IPWEA: Perth.

Lake, G (2015). Get the Facts: Sale of Aged Care Facilities. Accessed $15^{\text {th }}$ September 2015 at http://www.geofflake.com.au/aged-care/.

Local Government Career (2014). Suspension Kept Minutes From Central Darling's Return. Local Government Career: North Brighton.

Monash City Council (2015). Local Government Rates Capping and Variation Framework Review. Monash City Council: Monash.

Municipal Association of Victoria (MAV), 2012. Defined Benefits Superannuation Shortfall. MAV: Melbourne.

Oates, Wallace (2005). Toward a Second-Generation Theory of Fiscal Federalism. International Tax and Public Finance, 12: 349-373.

Office of Local Government (OLG) (2014). Fit for the Future - A Blueprint for the Future of Local Government. OLG: Sydney.

Office of Local Government (2015). Time Series Comparative Data 2012-2014. OLG:

Sydney.

Parliament of the Commonwealth of Australia. (2009). The Global Financial Crisis and Regional Australia: House of Representatives Standing Committee on Infrastructure, Transport, Regional Development \& Local Government. Parliament of Australia: Canberra.

Pilcher, R. (2002). Reporting of Roads by NSW Local Councils - Survival of the Fittest. Accounting, Accountability \& Performance 8(2): 23-41. 
Pilcher, R. and Van Der Zahn, M. (2010). Local Governments Unexpected Depreciation and Financial Performance Adjustment. Financial Accountability \& Management 26(3): 299-323.

Twomey, A (2012). Always the Bridesmaid - Constitutional Recognition of Local Government. Monash University Law Review, 38(2): 142-180.

Victorian Auditor-General's Office (VAGO) (2015). Local Government: Results of the 201314 Audits. VAGO: Melbourne.

Wallis, J. and Dollery, B. (1999). Market failure, Government Failure, Leadership and Public Policy. Macmillan: London.

Wittenhall, R. (2011). Global Financial Crisis: The Australian Experience in International perspective. Public Organization Review, 11: 77-91. 